\title{
The boundary between morphology and syntax: separable complex verbs in Dutch ${ }^{*}$
}

\author{
Geert Booij
}

\section{INTRODUCTION: THE PRINCIPLE OF LEXICAL INTEGRITY}

Probably the most fundamental principle of the lexicalist theory of word formation is the Principle of Lexical Integrity that is formulated as follows by Lapointe $(1980: 8):^{1}$

\section{Principle of Lexical Integrity \\ No syntactic rule can refer to elements of morphological structure.}

This formulation of the Principle of Lexical Integrity does not exclude all types of interaction between morphology and syntax. In particular, it does not exclude the possibility that phrases form parts of words. This is in accordance with ample empirical evidence that the so-called 'No Phrase Constraint' (a term from Botha 1984) is incorrect, as is shown in e.g. Dressler (1988) and Hoeksema (1988). Not only can lexicalized phrases form inputs for both compounding and derivation (as in the Dutch words God-is-dood-theologie 'God is dead-theology' and ban-debommer 'ban the bomb-er'), but certain types of phrases can productively be used as the specifier part of compounds in Dutch (e.g. NP's with adjectival specifiers as in $\left[\left[[\text { oude }]_{\mathrm{A}}[\text { mannen }]_{\mathrm{N}}\right]_{\mathrm{N}},[\text { huis }]_{\mathrm{N}}\right]_{\mathrm{N}}$ 'old men's home'). Similar evidence from Afrikaans is given in Botha $(1984: 28)^{2}$

Note that the Principle of Lexical Integrity does, however, predict that wordinternal phrases are not accessible to the rules of syntax.

In this paper I will deal with one of the claims implied by the Principle of Lexical Integrity, namely, that material cannot be moved out or into words. This hypothesis has received a great deal of discussion in the recent literature, notably by Baker (1988a, b) and Di Sciullo \& Williams (1987). Baker allows for syntactic rules of incorporation, which move $\mathrm{X}^{\circ}$-categories (both lexical morphemes and bound morphemes) and adjoin them to other words, thereby creating complex words in surface structure, whereas Di Sciullo \& Williams want to exclude such analyses. I will focus here on the other side of the coin, namely the claim that sublexical elements cannot be moved by syntactic rules out of the complex words to which they

Author's address: Vakgroep Taalkunde, Vrije Universiteit, P.O. Box 7161, 1007 MC Amsterdam, The Netherlands. 
belong in deep structure. I will show that the morphological and syntactic behaviour of an important class of verbs in Dutch, the so-called separable complex verbs (e.g. opbellen 'to phone') does not conflict with the prohibition on syntactic movement of sub-lexical elements out of words. I will argue that the separable complex verbs are phrasal constructs, and that the two parts, therefore, can be separated. Their word-like properties will be shown to follow from independently motivated principles. Moreover, I will show that these verbs cannot be analyzed as the result of a syntactic rule of incorporation.

\section{PHRASAL PROPERTIES AND WORD PROPERTIES OF SEPARABLE COMPLEX VERBS}

Dutch, like the related languages of German and Afrikaans, has a large class of separable complex verbs (SCV's) illustrated here by opbellen 'to phone' (in Dutch orthography SCV's are written as one word when the two constituents are adjacent). SCV's behave as phrases in that the two parts can be separated by rules such as Verb Second and Verb Raising, as illustrated in (2) and (3) respectively. Verb Second is the rule that moves the tensed verb into second position in main clauses, and presupposes that the underlying word order of Dutch is SOV (cf. Koster 1975). Verb Raising is the rule that raises the verb of an embedded clause to the right of the verb of the dominating clause where it forms a unit with that verb (Evers 1975).

DS John me op belde

SS John belde $\mathrm{i}_{\mathrm{i}}$ me op $\mathrm{t}_{\mathrm{i}}$

John rang me up

'John phoned me'

(3) DS dat John [PRO me op bellen] wil

SS dat John [PRO me op $\left.\mathrm{t}_{\mathrm{i}}\right]_{\text {, wil bellen }}$

that John [PRO me up $\mathrm{t}_{\mathrm{i}}$ ] wants ring $\mathrm{i}_{\mathrm{i}}$

'that John wants to phone me'

Note that instead of bellen it is also possible to raise opbellen:

$$
\begin{aligned}
& \text { dat John [PRO me } t_{i} \text { ] wil opbellen } \\
& \text { that John [PRO me } t_{i} \text { ] want up ring } \\
& \text { 'that John wants to phone me' }
\end{aligned}
$$

However, this does not imply that opbellen is one word. The facts are also explained if we assume that SCV's are minimal projections of $\mathrm{V}$ because verb projections can also be raised, as pointed out by Haegeman \& van Riemsdijk (1986: 419). For instance, in West Flemish both V and VP (i.e. V + direct object) can be raised. For standard Dutch we therefore assume that both $\mathrm{V}$ and $\mathrm{V}^{*}$ ( $=$ the minimal projection 
of V, itself dominated by the VP-node and the dominating node for SCV's) can be raised. In other words, I propose to assign the structure $[\mathrm{P} \mathrm{V}]_{\mathrm{V}^{*}}$ to $\mathrm{SCV}$ 's, where $\mathrm{P}$ stands for Particle.

The separability of SCV's can also be observed in the way they form their past participles. In Dutch, past participles are formed by prefixing $g e$ - and simultaneously suffixing $t / d$ to the verbal stem. However, in SCV's ge- occurs in between the particle and the verb: op-ge-beld. This follows directly from a phrasal analysis of such constructions, whereas it forms a problem in an analysis that assigns word status to SCV's. It was on the basis of such an observation that De Rooy-Bronkhorst (1980) proposed to assign phrasal status to SCV's.

This separability can also be observed with respect to the occurrence of the infinitival particle te that appears before verbal infinitives:

John belooft te komen 'John promises to come'

John belooft op te bellen 'John promises to ring'

That is, in infinitival forms of SCV's, te appears in between the two parts: op te bellen. Again, this argues in favor of a phrasal analysis of SCV's.

In what is probably the first generative analysis of verb-particle combinations, Koster (1975: 171) proposes to interpret them as compound verbs. For instance, opbellen is assigned the following structure:

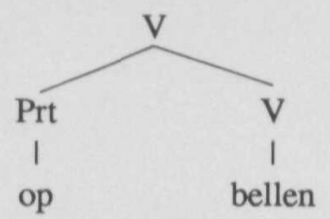

To account for the fact that only the base-V is moved by $\mathrm{V}$-second, leaving the particle behind, Koster assumes that V-second only applies to the tensed part of compound verbs. This means that we have to allow for syntactic rules that move sublexical elements out of words. Moreover, this solution presupposes that the feature [tense], for some reason, does not percolate from the head to the dominating V-node, contrary to standard assumptions about the percolation of morpho-syntactic features (cf. Lieber 1989).

This problem is also discussed by Groos (1989) who analyzes SCV's as cases of 'deep structure adjunction' (in opposition to Baker's (1988a) analysis of complex verbs as cases of surface structure adjunction). The hypothesis of deep structure adjunction means that verbs are (obligatorily or optionally) subcategorized for one or more particles that are adjoined to the verb, resulting in the following syntactic structure for SCV's: 
(7)

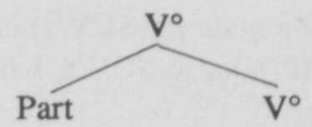

Verb Raising can now apply to either the lower or the higher V. Verb Second applies only to the lower $\mathrm{V}$ because the feature [tense] only occurs on the lower $\mathrm{V}$. This is based on the assumption that "feature percolation is limited to projections of heads, excluding thereby percolation to adjunction categories" (Groos 1989: 51).

In my opinion, Groos's analysis has a number of problematic aspects. Firstly, it remains unclear how a structural distinction is to be made between cases of deep structure adjunction and those of morphologically derived compound verbs, such as slaapwandelen 'to sleep-walk', which have a parallel structure:

(8)

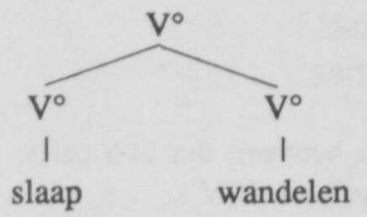

In other words, how can the percolation conventions see that wandelen is the head of slaapwandelen, yet that bellen is not the head of opbellen? Secondly, if V-raising can apply to either the lower or the higher $\mathrm{V}^{\circ}$, why is it incorrect to only raise wandelen?:

$$
\begin{aligned}
& \text { DS dat hij [PRO slaapwandelen] ging } \\
& \text { that he sleep-walk went } \\
& \text { that he went sleep-walking } \\
& \text { SS *dat hij [PRO slaap } \mathrm{t}_{\mathrm{i}} \text { ] ging wandelen }
\end{aligned}
$$

Finally, the deep structure adjunction hypothesis does not account for the effects of the addition of particles on the argument structure of the resulting SCV (see Section 3 ). The problem is that argument structure may not be changed in syntax, since this would violate the Projection Principle. This issue will be discussed in greater detail below.

Let us now discuss the observations that have led people to assign word status to SCV's, a position also reflected in the orthographical convention of writing Dutch $\mathrm{SCV}$ 's as one word. Before going into the details, I present a representative list of words that occur as first constituents of SCV's, and of comparable inseparable complex verbs (ICV's) with similar first constituents, as well; they are presented in their citation form, the infinitive, with the infinitival suffix -en: 
of V, itself dominated by the VP-node and the dominating node for SCV's) can be raised. In other words, I propose to assign the structure $[\mathrm{P} \mathrm{V}]_{\mathrm{V}^{*}}$ to $\mathrm{SCV}$ 's, where $\mathrm{P}$ stands for Particle.

The separability of SCV's can also be observed in the way they form their past participles. In Dutch, past participles are formed by prefixing $g e$ - and simultaneously suffixing $t / d$ to the verbal stem. However, in SCV's ge- occurs in between the particle and the verb: op-ge-beld. This follows directly from a phrasal analysis of such constructions, whereas it forms a problem in an analysis that assigns word status to SCV's. It was on the basis of such an observation that De Rooy-Bronkhorst (1980) proposed to assign phrasal status to SCV's.

This separability can also be observed with respect to the occurrence of the infinitival particle te that appears before verbal infinitives:

John belooft te komen 'John promises to come'

John belooft op te bellen 'John promises to ring'

That is, in infinitival forms of SCV's, te appears in between the two parts: op te bellen. Again, this argues in favor of a phrasal analysis of SCV's.

In what is probably the first generative analysis of verb-particle combinations, Koster (1975: 171) proposes to interpret them as compound verbs. For instance, opbellen is assigned the following structure:

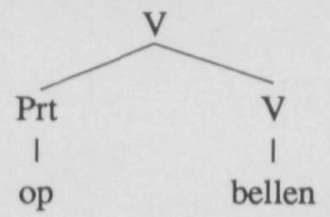

To account for the fact that only the base-V is moved by $\mathrm{V}$-second, leaving the particle behind, Koster assumes that V-second only applies to the tensed part of compound verbs. This means that we have to allow for syntactic rules that move sublexical elements out of words. Moreover, this solution presupposes that the feature [tense], for some reason, does not percolate from the head to the dominating $\mathrm{V}$-node, contrary to standard assumptions about the percolation of morpho-syntactic features (cf. Lieber 1989).

This problem is also discussed by Groos (1989) who analyzes SCV's as cases of 'deep structure adjunction' (in opposition to Baker's (1988a) analysis of complex verbs as cases of surface structure adjunction). The hypothesis of deep structure adjunction means that verbs are (obligatorily or optionally) subcategorized for one or more particles that are adjoined to the verb, resulting in the following syntactic structure for SCV's: 
(7)

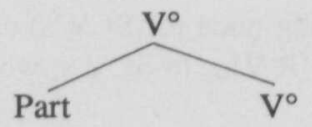

Verb Raising can now apply to either the lower or the higher V. Verb Second applies only to the lower V because the feature [tense] only occurs on the lower V. This is based on the assumption that "feature percolation is limited to projections of heads, excluding thereby percolation to adjunction categories" (Groos 1989: 51).

In my opinion, Groos's analysis has a number of problematic aspects. Firstly, it remains unclear how a structural distinction is to be made between cases of deep structure adjunction and those of morphologically derived compound verbs, such as slaapwandelen 'to sleep-walk', which have a parallel structure:

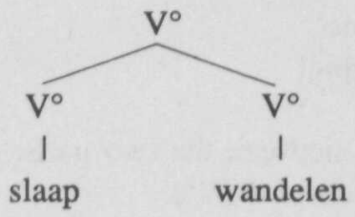

In other words, how can the percolation conventions see that wandelen is the head of slaapwandelen, yet that bellen is not the head of opbellen? Secondly, if V-raising can apply to either the lower or the higher $\mathrm{V}^{\circ}$, why is it incorrect to only raise wandelen?:

$$
\begin{aligned}
& \text { DS dat hij [PRO slaapwandelen] ging } \\
& \text { that he sleep-walk went } \\
& \text { that he went sleep-walking } \\
& \text { SS *dat hij [PRO slaap } \left.\mathrm{t}_{\mathrm{i}}\right] \text { ging } \text { wandelen }_{\mathrm{i}}
\end{aligned}
$$

Finally, the deep structure adjunction hypothesis does not account for the effects of the addition of particles on the argument structure of the resulting SCV (see Section 3). The problem is that argument structure may not be changed in syntax, since this would violate the Projection Principle. This issue will be discussed in greater detail below.

Let us now discuss the observations that have led people to assign word status to SCV's, a position also reflected in the orthographical convention of writing Dutch SCV's as one word. Before going into the details, I present a representative list of words that occur as first constituents of SCV's, and of comparable inseparable complex verbs (ICV's) with similar first constituents, as well; they are presented in their citation form, the infinitive, with the infinitival suffix -en: 
(10) SVC:

áan-blijven 'stay on' áchter-blijven 'stay behind'

áf-branden 'burn down'

bíj-betalen 'pay extra'

dóor-boren 'go on drilling'

ín-ademen 'inhale'

ná-kijken 'check'

néer-gooien 'throw down'

óm-blazen 'blow down'

ónder-gaan 'go down'

óp-komen 'come up'

óver-komen 'come over'

rónd-brieven 'tell around'

tégen-gaan 'combat'

úit-ademen 'breathe out'

uitéen-lopen 'diverge'

vóor-komen 'occur'

vóort-duren 'continue'

wéer-keren 'return'
ICV:

aan-bídden 'worship'

achter-hálen 'recover'

door-bóren 'perforate'

om-blázen 'blow around'

onder-gáan 'undergo'

over-kómen 'happen to'

voor-kómen 'prevent'

weer-gálmen 'echo'

Most of the words that occur as first constituents can also function as prepositions/ postpositions. However, mis, neer, uiteen, voort, and weer do not occur as adpositions, but only as adverbs. I will use the usual term 'particle' to refer to this class of separable adpositions (P) and adverbs (Adv).

There is also a small set of SCV's, the first constituent of which is either an adjective (e.g. goed-keuren 'to approve', vol-houden 'to go on'), a noun (e.g. ademhalen 'to breathe', stof-zuigen 'to vacuum clean', feest-vieren 'to have a party'), or a morpheme that does not exist as an independent word (e.g. gade-slaan 'to watch'). Two of these adjectives, vol 'full' and mis 'wrong', also occur as the first constituent of ICV's:
SCV
ICV
mís-grijpen 'miss one's hold'
mis-stáan 'not suit'
vól-houden 'maintain'
vol-bréngen 'accomplish'

In the case of Noun-Verb combinations their unity can be observed in that they take niet as their negative element (= the negative element for verbs), whereas a syntactically independent NP takes geen as its negative element:
a. Hij kon niet / geen adem halen
'He could not breathe' 


\section{b. Hij kon *niet / geen adem krijgen \\ 'He could not get breath'}

The fact that in (12a) both niet and geen can occur follows from the ambiguity of adem halen. It is an established SCV (and thus selects niet), but can also be interpreted as a VP with the generic noun adem as its direct object (with concomitant selection of geen). Also compare the following sentences:
a. Hij kan niet stofzuigen
'lit. He cannot dust-suck'
'He cannot vacuum-clean' (= He cannot work with a vacuum-cleaner)
b. Hij kan geen stof zuigen
'He cannot suck dust'

In (13a) we find the established SCV stofzuigen with the idiosyncratic meaning 'to vacuum-clean', whereas in (13b) we are forced to assign a literal interpretation to stof zuigen.

Given the remarkable similarity between the SCV's and the ICV's illustrated in (10) it becomes clear that it will be hard to account for their difference in separability if both types are assigned word status. For instance, why is it possible to separate the two parts of overkomen 'to come over', whereas this is impossible in overkómen 'to happen to'? This difference follows straightforwardly if SCV's and ICV's have the following structures:

$$
\begin{array}{ll}
\text { SCV: } & {[[\mathrm{X}][\mathrm{V}]]_{\mathrm{V}^{*}}}
\end{array} \quad(\mathrm{X}=\mathrm{P}, \mathrm{Adv}, \mathrm{A}, \mathrm{N})
$$

The existence of such minimal pairs is therefore the main empirical stumbling block for the proposal by Le Roux (1988) to consider SCV's as verbal compounds and to interpret the rule of V-second as a case of Head Movement in the sense of Baker (1988a).

Why then are people inclined to assign word status to SCV's? One reason is that they frequently function as inputs for deverbal word formation processes (14a) and compounding (14b):

a. aanbied-en 'to offer'

aankom-en 'to arrive' aantrekk-en 'to attract' aanton-en 'to demonstrate'

b. opberg-en 'to store' doorkijk-en 'to see through' aanbied-er 'offerer' aanbied-ing 'offer' aankom-st 'arrival' aantrekk-elijk 'attractive' aantoon-baar 'demonstrable' opbergdoos 'store box' doorkijkbloes 'see through blouse' 
However, this does not contradict a syntactic analysis of SCV's. As we saw in Section 1, not all word formation is exclusively word-based: the No Phrase Constraint is empirically incorrect, and phrases may occur as parts of complex words.

On the other hand, this does not mean that all word formation rules accept syntactic inputs. For instance, prefixes do not attach to syntactic phrases, and, more generally, phrases normally do not occur as the heads of words in Dutch. ${ }^{3}$ This is very relevant to the problem under discussion. For instance, the deverbal prefix vercan be attached to ICV's, but not to SCV's:
a. with IVC's: veronderstéllen 'presuppose'
veroverhéersen 'overrule' vervolmáken 'make perfect'
b. with SVC's: *veróvermaken, *vervólmaken

This simply follows from the prohibition on phrases as heads or as inputs for prefixation, if we assign SVC's the $\mathrm{V}^{*}$ status. ${ }^{4}$

A second reason for assigning word status to SCV's is the fact that their semantic interpretation is usually partially or completely unpredictable. This is similar to what we find for English verb-particle combinations such as to look for, to look after etc. Some examples are given in (16).

$$
\begin{aligned}
& \text { vangen 'to catch' } \\
& \text { slaan 'to hit' } \\
& \text { wenden 'to turn' } \\
& \text { heffen 'to raise' }
\end{aligned}
$$

$$
\begin{aligned}
& \text { aanvangen 'to begin' } \\
& \text { aanslaan 'to start barking' } \\
& \text { aanwenden 'to use' } \\
& \text { aanheffen 'to start singing' }
\end{aligned}
$$

Semantic idiosyncrasy, however, is not a proper criterion to distinguish words and phrases, since there are many idiosyncratic expressions for which there is no doubt as to their status of syntactic constructs (cf. Di Sciullo \& Williams 1987). The only consequence is that many SCV's have to be listed in the lexicon. This is also necessary for formal reasons: some SCV's contain parts that do not occur as independent words, 'cranberry morphs' in the terminology of Aronoff (1976):
a. first part non-existent: gade-slaan 'to watch'
b. second part non-existent:
na-bootsen 'to imitate' om-kukelen 'to fall down' aan-tijgen 'to accuse' op-kalefateren 'to restore' 
A third observation that has led linguists to consider SCV's as words is the fact that the particles, like (real) prefixes, seem to have the power to change the syntactic category of the input words. In Dutch, prefixes such as be-and ver-derive verbs from verbs, nouns, and adjectives, and hence have category-changing power, which is characteristic of derivational morphology. The separable particles also seem to have this power; witness the data in (18):

$$
\begin{aligned}
& \text { input A: } \\
& \text { dik 'thick' } \\
& \text { zwak 'weak' } \\
& \text { snel 'fast' } \\
& \text { diep 'deep' }
\end{aligned}
$$

\section{input $N$ :}

burger 'citizen'

aap 'monkey'

brief 'letter'

huwelijk 'marriage'
SCV:

indikken 'to thicken'

afzwakken 'to weaken'

toesnellen 'to rush forward'

uitdiepen 'to deepen'

SCV:

inburgeren 'to settle'

naapen 'to imitate'

rondbrieven 'to tell around'

uithuwelijken 'to marry off'

Suppose that these facts would induce us to consider the formation of SCV's as part of morphology. It would then be impossible to consider them as compounds, because in Dutch compounds it is the right constituent that is the head and that determines the syntactic category of the resulting complex word, whereas in the examples listed in (18), the right constituent does not determine the syntactic category. Hence, words like in-, af-, na-, toe- and rond- would have to be considered as derivational prefixes, because derivational prefixes can change the syntactic category of their base words. We then end up with a situation in which prefixes, although they are bound morphemes, can nevertheless be separated from the base word to which they are attached. It will be clear that this is a major drawback for a prefixal interpretation of the first constituents of SCV's, and therefore, another analysis is called for.

My analysis is as follows: in Dutch, the conversion of adjectives and nouns into verbs is productive. Hence, a verb like zwakken as used in afzwakken is a possible word of Dutch. This possible word is only used in combination with the particle af. As has been argued in Booij (1977) and Allen (1978), for example, possible though not existing words are often used in creating complex expressions. Therefore, what I assume here is that these possible verbs, created from adjectives and nouns by conversion, are available for the creation of particle-verb combinations.

Independent evidence for this analysis is that conversion to verbs in Dutch normally only applies to simplex adjectives and nouns (Van Marle 1985). This makes the correct prediction that, although both verbal prefixes (19a) and particles (19b) can occur with complex verbs, the apparently category-changing particles are only found to co-occur with mono-morphemic words. ${ }^{5}$ 
(19)
a. $\left[\text { on }[\text { geluk }]_{N}\right]_{N}$ 'accident'
verongelukken 'to die in an accident' [ootmoed $\left.]_{N^{1 g}}\right]_{A}$ 'humble' verootmoedigen 'to humble'
b. [ver[huren $\left.]_{\mathrm{V}}\right]_{\mathrm{V}}$ 'let' verontschuldigen ${ }^{6}$ 'to excuse' $[\text { [analys }]_{\mathrm{N}}$ eren $]_{\mathrm{V}}$ 'analyze' onderverhuren 'to sublet' dooranalyseren 'completely analyze'

A final argument for giving a morphological interpretation to the creation of SCV's is that the addition of particles quite often affects the syntactic valency of the verb, just like (real) prefixes. This phenomenon is discussed in detail in the following section. There it will be argued that changes in syntactic valency follow from changes in the lexical-conceptual structure of linguistic expressions. Hence, since the addition of particles affects the lexical conceptual structure of the particle-verb combination, the syntactic valency of an SCV may be different from that of the verb that it contains. As will be argued below, these observations do not force us to consider the formation of SCV's as cases of prefixation, but they do show that the formation of SCV's cannot be a matter of syntax.

In sum, the word-like properties of SCV's and the prefix-like properties of particles as discussed so far, are not in conflict with a phrasal analysis of SCV's, an analysis that also accounts for the differences in both syntactic and morphological behavior between SCV's and ICV's.

\section{SYNTACTIC VALENCY CHANGE AND SYNTACTIC ACCOUNTS OF SCV'S}

Dutch verbal prefixes may have effects on the syntactic valency of the input words. For instance, the prefix be- systematically creates obligatorily transitive verbs from both intransitive and transitive input verbs (cf. Booij \& Van Haaften 1988). A parallel phenomenon occurs with certain particle-verb combinations.

$$
\begin{aligned}
& \text { bellen (opt. tr.) 'phone' / iemand opbellen 'phone somebody' } \\
& \text { lopen (intr.) 'walk' / de straten aflopen 'tramp the streets' } \\
& \text { rijden (intr.) 'ride' / de auto inrijden 'run in the car' } \\
& \text { wonen (intr.) 'live' / een vergadering bijwonen 'attend a meeting' } \\
& \text { juichen (intr.) 'cheer' / iemand toejuichen 'cheer somebody' } \\
& \text { zitten (intr.) 'sit' / een straf uitzitten 'serve one's time' }
\end{aligned}
$$

Transitivization is not the only effect on syntactic valency of the addition of a particle to a verb. In other cases, the effect is 'ergativization', i.e. the creation of a (superficially intransitive) verb that selects zijn as its auxiliary. According to Hoekstra (1984), such ergative verbs do not have an external argument. The internal argument is moved to the subject position in surface structure. Hence we have to distinguish between intransitive verbs (external argument only), transitive verbs (internal and external argument), and ergative verbs (internal argument only). The 
ergativization effect is illustrated in (21) and (22) - the difference between the two classes to be discussed below:
glijden 'glide' / uitglijden 'slide'
vliegen 'fly' / uitvliegen 'fly away'
marcheren 'march' / afmarcheren 'march away'
lopen 'walk' / weglopen 'walk away'
zwaaien 'wave' / afzwaaien 'leave military service'

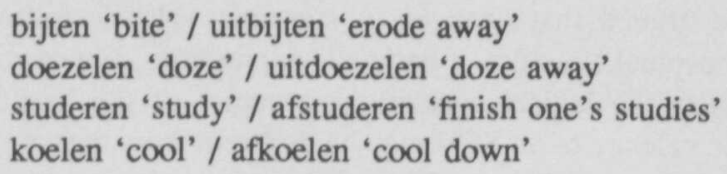

Although syntactic valency changes do occur as a result of derivational processes, it is not necessarily the case that valency change always indicates the process at hand to be a derivational one. Since argument structure is a projection of Lexical Conceptual Structure (Zubizarreta 1987, Booij \& van Haaften 1988, Booij 1989, Carrier and Randall, ms.), valency changes can be seen as the effects of the semantic changes brought about by the combination of particles and verbs. However, before defending this position in more detail, I will discuss another, purely syntactic approach to Particle-Verb combinations, because this will serve to elucidate the range of facts that have to be accounted for.

Following a suggestion in Kayne (1984), Hoekstra et al. (1987) propose a Small Clause analysis for SCV's. Their main argument is that the SC-analysis explains the transitivization effect illustrated in (20):

$$
\begin{aligned}
& \text { a. dat ik [Peter op }]_{S C} \text { bel } \\
& \text { that } I \text { Peter on phone = 'that I phone Peter' } \\
& \text { b. dat ik [de auto in }]_{S C} \text { rijd } \\
& \text { that } I \text { the car in run = 'that I run in the car' }
\end{aligned}
$$

That is, sentences with SCV's are analyzed as containing a resultative small clause of which the particle is the predicate, and thus they are claimed to be similar to resultative small clauses such as

$$
\begin{aligned}
& \text { dat ik [de deur groen }]_{\mathrm{SC}} \text { verf } \\
& \text { that } \mathrm{I} \text { the door green paint }=\text { 'that I paint the door green' }
\end{aligned}
$$

In other words, what look like the internal arguments of opbellen and inrijden, respectively, are the subjects of small clauses. That is, the transitivization effect is analyzed as the effect of the necessary presence of an overt subject in the resultative small clause. 
For ergative SCV's such as wegsterven 'die out', Hoekstra et al. (1987: 68) propose the following analysis, illustrated by (25):

dat het geluid ${ }_{\mathrm{i}}\left[\mathrm{t}_{\mathrm{i}} \text { weg }\right]_{\mathrm{SC}}$ sterft

that the sound away dies = 'that the sound fades away'

That is, since sterven is an ergative verb with no underlying subject, the subject of the small clause is moved to the subject position.

This analysis covers two kinds of effect on syntactic valency: (i) transitivization and (ii) no change for SCV's that contain ergative verbs. However, we also find cases of ergativization, as shown in (21)-(22). The verbs in (21) are either intransitive or ergative, i.e. they occur with both hebben and zijn. They are ergative when combined with a directional adverbial. Compare (26a) with (26b):

a. Ik heb gevlogen 'I have flown'

b. Ik ben naar Amsterdam gevlogen 'I have flown to Amsterdam'

Hoekstra et al. (1987) analyze naar Amsterdam in (26b) as the predicate of an SC. Hence, the ergative variant of movement verbs such as vliegen can be used in combination with a directional SC:

\section{dat $\mathrm{ik}_{\mathrm{i}}\left[\mathrm{t}_{\mathrm{i}}\right.$ naar Amsterdam] gevlogen ben}

If this analysis is correct, it might also be used to explain the ergativity of the Particle-Verb combinations in (21), since the particles may be claimed to be directional predicates. However, the ergativity effect also occurs in the SCV's in (22), where the base verbs do not express some kind of movement. That is, the ergativity effect in this case cannot be said to follow from already available syntactic generalizations. Rather, what seems to be going on here is that the SCV expresses a change of state, unlike the corresponding single verbs, and changes of state are usually expressed as ergative verbs in Dutch (e.g. breken 'to break, erg.', sterven 'to die').

The crucial role of semantic (i.e. lexical-conceptual) structure in the determination of the syntactic valency of SCV's is also supported by the two uses of aflopen and afslaan (from lopen 'to walk' and slaan 'to hit'):

(28) De wekker loopt af (erg.)

'The alarm clock goes off'

Hij liep de hele tentoonstelling af (tr.)

'He did the whole exposition' 
De motor slaat af (erg.)

'The engine stops'

Hij sloeg de uitnodiging af (tr.)

'He turned down the invitation'

Although af may have a directional interpretation (as in afmarcheren 'to march away') the ergativity or transitivity of a Prt-V combination completely depends on its meaning. Since both aflopen and afslaan have (at least) two semantic interpretations, they have two syntactic valencies. A comparable minimal pair is afnemen (erg.) 'to decrease' versus afnemen (tr.) 'to take away'.

More generally, particles with a directional interpretation do not always enforce ergativity, as is shown, for example, by the particle uit 'outward'. The following Prt-V combinations are all transitive:

$$
\begin{aligned}
& \text { uitbazuinen 'to trumpet' } \\
& \text { uitbesteden 'to farm out' } \\
& \text { uitstomen 'to dry-clean' } \\
& \text { uitvegen 'to wipe out' }
\end{aligned}
$$

Another empirical problem for the SC analysis of Prt-V combinations is that, in many cases, they keep the intransitivity of their verbal constituent. In such cases the $\mathrm{SC}$ analysis is impossible, as illustrated by the SCV doorwerken 'to go on working'. Note that werken is an intransitive verb, and that the intransitive doorwerken selects hebben as its auxiliary.

\section{dat ik [? door $]_{\text {sc }}$ gewerkt heb}

that I through worked have $=$ 'that I went on working'

As Hoekstra et al. (1987: 68) point out, the subject of the small clause cannot be PRO since it is a governed position. Hence, it would have to be interpreted as an adjunct small clause, comparable to (32):

$$
\text { dat Jan [PRO bedroefd] zijn brood at }
$$

that John sad his bread ate $=$ 'that John ate his bread sad'

However, particles cannot be interpreted as the heads of adjunct SC's. Firstly, particles only occur before verbs whereas adjunct SC's can also occur before the subject or the direct object:

(33) Jan at zijn brood op/bedroefd Jan at bedroefd/*op zijn brood Bedroefd/*op at Jan zijn brood 
Secondly, the particle does not predicate anything of the antecedent of PRO.

This problem for the SC analysis does not bear an incidental character: a number of particles preserve the syntactic valency (in these examples the intransitivity) of the verbs, e.g., door, omhoog, op, voor, voorop, rond:

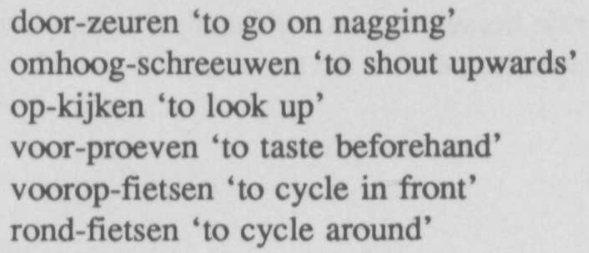

This problem might seem to be solved if one were not to consider these particles as the heads of small clauses, but as adverbs that have been incorporated into the verb by $\mathrm{X}^{\circ}$-movement instead. However, as I will argue below, an incorporation analysis is also problematic.

To sum up what we have seen so far in this section: an empirical obstacle for an $\mathrm{SC}$ analysis of Part-V combinations is that, in many cases, the predicted transitivization effect does not occur, and that the ergativization effect does not follow from available generalizations concerning the change of non-ergative verbs into ergative ones. This suggests a crucial role for the semantic properties of the Prt-V combinations in accounting for their syntactic valency.

Another problem for the SC analysis is the following: As shown by Verb (Projection) Raising, Prt-V combinations behave as a unit. Therefore, as Groos (1989) points out, the SC analysis requires that, before Raising applies, the particle (i.e. the predicate of the small clause) is adjoined to the $\mathrm{V}$ of the dominating clause, presumably by Head Movement (Baker 1988a: 54), which adjoins a word of the category $\mathrm{X}^{\circ}$ to its proper governor $\mathrm{Y}^{\circ}$. Groos shows that this consequence of the $\mathrm{SC}$ analysis creates new problems:

While particles are free to incorporate, i.e., to move along with the verb under V[erb] R[aising], intransitive prepositions are not. Consider the following sentences containing intransitive prepositions:

(a) Jan heeft altijd boven willen wonen

'Jan has always up(stairs) wanted to-live'

(b) *Jan heeft altijd willen boven wonen

'Jan has always wanted up(stairs) to-live'

In the ungrammatical sentence above, [(b)], the intransitive preposition has been incorporated into $\mathrm{V}$ and moved along with the verb under VR.

(Groos 1989: 53)

Consequently, the application of Head Movement has to be restricted by lexical information: which elements can be incorporated (and what the meaning of the resulting SCV is) has to be lexically encoded on the verb. Although this is not 
impossible, it is an unattractive solution given the productivity of the class of SCV's (see below). Moreover, it still does not explain why the rule of Verb Second does not apply to the whole Prt-V combination, but to the verbal part only.

Finally, note that the SC analysis does not cover those SCV's that do not form Prt-V combinations or A-V combinations, i.e. SCV's in which the first constituent is a noun, such as paardrijden 'to ride horseback'. An SC analysis would require a structure of the following kind, in which paard is the predicate of the SC:

$$
\begin{aligned}
& \text { dat Jan }[? \text { paard }]_{S C} \text { reed } \\
& \text { 'that Jan horse rode' }
\end{aligned}
$$

Clearly, such a structure is impossible due to the absence of a proper subject for the SC.

In Van Riemsdijk (1978) we find another syntactic approach to SCV's. Van Riemsdijk proposes to consider particles as intransitive pre/postpositions in underlying structure. They are then adjoined to the following verb by a rule of incorporation. This proposal, of course, reminds us of the more general proposal of Baker (1988a) to interpret incorporation as $\mathrm{X}^{\circ}$-movement to the head. As Groos (1989) correctly points out, such a rule of Incorporation would have to be governed lexically, since incorporation normally is not optional. Compare (36), in which the intransitive preposition is preposed with (37), in which the particle must be incorporated and cannot be preposed:
a. Ik wil niet voor wonen
'I do not want to live in front'
b. Vór wil ik niet wonen
a. Ik wil niet voor sorteren
'I do not want to get in lane'
b. *Vóór wil ik niet sorteren

The problem is not so much that Incorporation would be lexically governed, in the sense that the lexicon would define which incorporated structures are acceptable (this assumption is also made in Baker 1988a), but that the obligatory application of this rule would not follow from other principles. The words that are subject to incorporation are lexical morphemes, and hence their obligatory incorporation does not follow from their being bound morphemes.

An incorporation analysis would also cause problems for SCV's with nouns as first constituents, because it predicts the wrong adjectival form geen instead of the adverbial form niet (see (13)):

$$
\begin{aligned}
& \text { DS: dat ik geen stof zuig } \\
& \text { SS: *dat ik geen } t_{i} \text { [stof zuig] }
\end{aligned}
$$




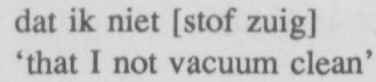

This shows that stof and zuig should already form a unit at deep structure, in order to receive the right form of the negative element.

As we saw above, SCV's are frequently inputs for compounding and derivation. This is also a problem for the incorporation analysis as proposed by Van Riemsdijk (and presupposed in the SC analysis), because the SCV's in such analyses only form a unit at the level of surface structure, whereas there is no evidence that the derivational and compounding rules involved can apply as part of the syntactic derivation. On the contrary: since derivational rules, such as deverbal -er-affixation, affect the argument structure of the input verbs, the Projection Principle requires such derivational processes to take place pre-syntactically.

Finally, note that Van Riemsdijk's incorporation analysis does not account for the effects of particle incorporation on the syntactic valency of the verbs.

In sum, an analysis is called for that analyzes SCV's as phrasal constructs without creating them by means of syntactic movement rules.

\section{A LEXICAL ACCOUNT OF SCV'S}

It is a fairly generally accepted assumption that lexicalized syntactic phrases may be listed in the lexicon. However, it is incorrect to use this assumption to account for SCV's. Clearly, not all SCV's are lexicalizations. An account in terms of lexicalization is probably all right for SCV's with nouns and adjectives as their first constituents, such as [goed $]_{\mathrm{A}}[\text { keuren }]_{\mathrm{V}}$ 'to approve' and [adem $]_{\mathrm{N}}[\text { halen }]_{\mathrm{V}}$ 'to breathe', because these SCV's may have arisen through reanalysis of syntactic structure, e.g. dat ik [dat goed] keur 'lit. that I that right judge' $\rightarrow$ dat ik dat [goed keur] 'that I approve of that'. Note that the class of SCV's with nominal or adjectival first constituents is not productive. Some particle-verb combinations may also have arisen through lexicalization. On the other hand, the class of SCV's with particles is very productive, and can be extended unintentionally, with transparent meanings. For instance, the particle door can be used with all kinds of action verbs, with the predictable meaning 'to go on V-ing':

$$
\begin{aligned}
& \text { doorschrijven 'to go on writing' } \\
& \text { doorkopen 'to go on buying' } \\
& \text { doortikken 'to go on typing' } \\
& \text { doordrinken 'to go on drinking' }
\end{aligned}
$$


Similarly, the particle mee has the meaning 'to join in V-ing':

$$
\begin{aligned}
& \text { meedenken 'to join in thinking', } \\
& \text { meeschrijven 'to join in writing' } \\
& \text { meefietsen 'to join in cycling' } \\
& \text { meeschelden 'to join in cursing' }
\end{aligned}
$$

This suggests that the stock of expressions in the Dutch lexicon can be extended in two ways: by morphological rules that create complex words dominated by an $\mathrm{X}^{\circ}$ category, and by rules that create a specific kind of phrasal construct, namely $[[\mathrm{Prt}][\mathrm{V}]]_{\mathrm{V}}{ }^{*}$, where $\mathrm{V}^{*}$ stands for the node in between $\mathrm{V}$ and the projection of $\mathrm{V}$ that dominates $\mathrm{V}$ and its possible objects. Whereas phrasal structure at the sentence level, in particular the VP constituent, may be seen basically as a projection of the lexical properties of the words, this is not the case for the minimal phrase [Prt V]. For instance, there is nothing in the argument structure of the verb bellen 'to phone' that requires the particle $o p$ to be there. This, of course, supports the view that SCV's are accounted for by rules in the lexicon, because lexical rules are optional. Instead of assuming a rule for each particle (in the spirit of Aronoff 1976), one could also provide specific lexical entries for particles, entries that specify both their particular meaning contribution to SCV's, and the fact that they combine with V's (e.g. by $\left.[--\mathrm{V}]_{\mathrm{V}^{*}}\right)$, similar to what Lieber $(1980)$ proposed for affixes. Note that the meaning of productive particles such as door is much more specific than their adverbial/ adpositional counterparts. For instance, the particle door either means 'to go on V-ing' or 'to V completely'.

As far as the changes in syntactic valency brought about by adding particles to verbs, the following should be remarked. As already pointed out above, the argument structure of a verb should be seen as a projection of its lexical-conceptual structure. Whether the particle affects syntactic valency depends on its meaning. For instance, the particles door and mee (cf. 40-41) affect the lexical-conceptual structure of the verb given their meanings 'go on with V-ing' and 'to join in V-ing', respectively, where V stands for an intransitive verb; but this change in meaning has no effect on argument structure, because the number of participants involved is not changed. Therefore, the same argument structure will be projected, and hence the syntactic valency does not change. Both door and mee require that the verb with which they combine be an intransitive one, as witnessed by the ungrammaticality of sentences such as (42):

$$
\begin{aligned}
& \text { a. *dat we de appels dooreten } \\
& \text { that we the apples through eat = 'that we go on eating apples' } \\
& \text { b. *dat we de appels meeëten } \\
& \text { that we the apples with eat = 'that we join in eating apples' }
\end{aligned}
$$


Therefore, SCV's with door and mee are intransitive.

There are also cases, however, in which the syntactic valency does change. Above, we saw the example afstuderen 'to finish one's studies' that denotes a change of state, whereas studeren 'to study' denotes an activity. In Dutch, changes of state are expressed as ergative verbs, and activities as (optionally) transitive verbs. This explains the change in syntactic valency from studeren to afstuderen. The same contrast is found in nemen 'to take' (obl. tr.) versus afnemen 'to decrease' and toenemen 'to increase': it is the idiosyncratic interpretation of the SCV's with nemen that predicts the syntactic ergativity of such verbs. The transitivization effect of certain particles, as discussed in Section 3, follows from the fact that by adding a particle such as $o p$ in opbellen 'to phone' or af in aflopen 'to tramp' it is expressed that the action mentioned by the verbs is directed towards an object in such a way that the object is somehow affected by that action. Therefore, the well known generalization that verbs with affected objects are expressed as transitive verbs (cf. Booij \& van Haaften 1988) can also be used to explain the transitivization effect of particles such as $o p$ and $a f$ on some of the verbs with which they occur.

\section{CONCLUSIONS}

In this paper I have shown that SCV's should not be considered as words, but rather as phrases that are created in the lexicon. Hence, we are not forced to assume that rules such as Verb Raising and Verb Second are allowed to move sub-lexical elements. This analysis, therefore, is in agreement with a specific subclaim of the Lexical Integrity Hypothesis, namely, the claim that sublexical elements cannot be moved out of words.

The analysis defended here also implies the rejection of a syntactic incorporation analysis of SCV's, but this, of course, does not allow us to conclude that incorporation analyzes for other phenomena should similarly be rejected. That is, we can only conclude here that it is possible to give an account of SCV's that is in agreement with both the claim that sublexical elements cannot be moved out of words, and the claim that (sub)lexical elements cannot be moved into words.

Further investigation is required to determine how the notion 'minimal projection of V', a level in between V and the level that includes objects, can be incorporated in the theory of projection levels in a non-ad hoc manner. For instance, one might ask whether there are languages other than just Dutch and some other Germanic languages, that require such a level of projection, either for $\mathrm{V}$ or for another lexical category. 


\section{NOTES}

* Previous versions of this paper were read at a meeting of the Jonge Onderzoekers of the University of Utrecht, at a workshop of the Max Planck Institut für Psycholinguistik in Nijmegen, and at the 4th International Morphology Meeting, Veszprém, Hungary. I would like to thank the audiences at those meetings, the anonymous referees, and the guest editors for their useful comments.

1. Compare the following definition of the Lexicalist Hypothesis in Anderson (1989: 1): "The syntax neither manipulates nor has access to the internal form of words".

2. A consequence of the fact that word formation allows for syntactic inputs is that the Principle of Lexical Integrity does not simply follow from an organization of the grammar in which morphology and syntax are assigned to completely separated components, as was suggested by Di Sciullo \& Williams (1987: 46).

3. Exceptions are those phrases which function as names, such as vliegende schotel 'flying saucer' from which the compound nep-vliegende schotel 'fake flying saucer' can be coined (example suggested to me by one of the referees).

4. This restriction holds only for unstressed prefixes. The prefix her- 're-' that bears main stress can combine with SCV's, e.g. her-aan-besteden 'to put out to bid again', her-in-delen 'to rearrange' etc.

5. The only exception in the data at hand (cf. 18) is uithuwelijken since the noun huwelijk is derived from the verb huw(en) 'to marry'. Note, however, that huwelijk has probably lost its morphological and semantic transparency, because -elijk is an unproductive suffix, and the verb huwen is rather obsolete, in contrast to the word huwelijk itself.

6. In the prefix sequence ver-on a $t$ is inserted after on-.

7. One of the referees pointed out to me that a similar notion, the notion 'verboid' is used in Coopmans \& Everaert (1988) for the unit formed by the verb laten 'to let' plus a following verb. The verb laten is similar to particles in SCV's in that it can affect the argument structure of the following verb, but nevertheless exhibits the syntactic behaviour of an independent syntactic unit.

\section{REFERENCES}

Allen, M.R. 1978. Morphological Investigations. Diss., Univ. of Connecticut.

Anderson, S.R. 1989. "Lexicalism and the distribution of reflexives". Yearbook of Morphology 2, 1-19. Aronoff, M. 1976. Word Formation in Generative Grammar. Cambridge Mass.: MIT Press.

Baker, M. 1988a. Incorporation. Chicago: Chicago University Press.

Baker, M. 1988b. "Review of Di Sciullo and Williams 1987". Yearbook of Morphology 1, 259-283.

Booij, G.E. 1977. Dutch Morphology. A Study of Word Formation in Generative Grammar. Dordrecht: Foris Publications.

Booij, G.E. 1989. "Morphology, semantics and argument structure". (VU Working Papers in Linguistics \# 33).

Booij, G.E. and T. van Haaften. 1988. "On the external syntax of derived words: evidence from Dutch". Yearbook of Morphology 1, 29-44.

Botha, R.P. 1984. Morphological Mechanisms. Lexicalist Analysis of Synthetic Compounding. Oxford etc.: Pergamon Press.

Carrier, J. and J. Randall. Ms. From Conceptual Structure to Syntax.

Coopmans, P. and M. Everaert. 1988. "The simplex structure of complex idioms: the morphological status of laten". In M. Everaert et al. (eds.), Morphology and Modularity. Dordrecht: Foris Publications, 75-104.

De Rooy-Bronkhorst, A. 1980. "Past participle ge-deletion and the role of stress in Dutch complex verbs". In W. Zonneveld et al. (eds.), Studies in Dutch Phonology. The Hague: Martinus Nijhoff, 159-204. 
Di Sciullo, A.-M. and E. Williams. 1987. On the Definition of Word. Cambridge Mass.: MIT Press.

Dressler, W. 1988. "Preferences vs. strict universals in morphology: word-based rules". In M. Hammond and M. Noonan (eds.), Theoretical Morphology. Orlando etc.: Academic Press, 143-154.

Evers, A. 1975. The Transformational Cycle in Dutch and German. Ph.D. Diss., Univ. of Utrecht.

Groos, A. 1989. "Particle-verbs and adjunction". In H. Bennis and A. van Kemenade (eds.), Linguistics in the Netherlands 1989. Dordrecht: Foris Publications, 51-60.

Haegeman, L. and H. van Riemsdijk. 1986. "Verb projection raising, scope, and the typology of rules affecting verbs". Linguistic Inquiry 17, 417-466.

Hoeksema, J. 1988. "Head-types in morpho-syntax". Yearbook of Morphology 1, 123-38.

Hoekstra, T. 1984. Transitivity. Dordrecht: Foris Publications.

Hoekstra, T. et al. 1987. "Complexe verba". Glot 10, 61-78.

Kayne, R. 1984. Principles of Particle Constructions. Ms.

Koster, J. 1975. "Dutch as an SOV language". In A. Kraak (ed.), Linguistics in the Netherlands 19721973. Assen: Van Gorcum, 165-177.

Lapointe, S. 1980. A Theory of Grammatical Agreement. Doct. diss, Univ. of Amherst.

Le Roux, C. 1988. On the Interface of Morphology and Syntax. Stellenbosch Papers in Linguistics \# 18.

Lieber, R. 1980. On the Organization of the Lexicon. Doct. diss., MIT [Published by Indiana Univ. Linguistics Club, 1981].

Lieber, R. 1989. “On percolation”. Yearbook of Morphology 2, 95-138.

Marle, J. van. 1985. On the Paradigmatic Dimension of Morphological Creativity. Dordrecht: Foris Publications.

Riemsdijk, H. van. 1978. A Case Study in Syntactic Markedness. Dordrecht: Foris Publications.

Zubizarreta, M.-L. 1987. Levels of Representation in the Lexicon and in the Syntax. Dordrecht: Foris Publications. 